\title{
Gas migration mechanisms from accumulation to surface
}

\author{
C. J. CLAYTON AND S. J. HAY
}

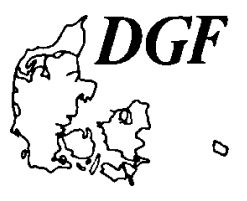

Clayton, C. J. and Hay, S. J.: Gas migration mechanisms from accumulation to surface. Bulletin
of the Geological Society of Denmark, Vol. 41, pp. 12-23. Copenhagen, 1994-03-30.
https://doi.org/10.37570/bgsd-1995-41-03

The driving force for gas migration is buoyancy, aided in some cases by sediment overpressure gradients (pressures above hydrostatic). Resistance to migration is controlled by the capillary entry pressure into the pore network of the overlying sediments, or by their resistance to fracturing. It can be shown that migration mechanisms vary with depth. Below the upper few hundred metres gas migrates by invading the pore network of the sediment whereas at shallower depths fracturing may occur preferentially. Thus even though gas appears to seep into the water column from fractures it will be more dispersed below the sediment surface. In addition, gas shows a tendency to "pond" in near surface sediments, which can be explained as a function of sediment compaction with depth and decreasing gas-water interfacial tension.

Approximate calculations of seal leakage rates are possible using a modified Darcy flow equation. For capillary failure of a mudstone seal at $3 \mathrm{~km}$ depth, gas fluxes are in the order of $.0015 \mathrm{~m}^{3} / \mathrm{m}^{2} /$ year at ambient pressure or $0.23 \mathrm{~m}^{3} / \mathrm{m}^{2} /$ year at surface conditions. Flow rates from fractured seals depend on the amount of time the fracture remains open. They vary from a value similar to that for capillary failure if the fracture is open for an average of one minute per year, to five or six orders of magnitude faster. The calculated capillary failure fluxes are comparable to measured surface gas seepage fluxes.

C. J. Clayton, School of Geological Sciences, Kingston University, Penrhyn Road, Kingston upon Thames, Surrey, KT1 2EE, U.K. S. J. Hay, BP-Statoil Alliance, Ranheimsveien 10, 7004 Trondheim, Norway. October 22nd, 1992.

\section{Introduction}

Gas seepages, both onshore and offshore, frequently arise from leakage of a structure at depth rather than from continuous flow from the site of formation of the gas, either biogenically or thermally from breakdown of kerogen. In studying gas seeps it is therefore important to understand how, and at what rates, the gas migrates to the surface. This is particularly important since direct observations are concentrated on the very shallow subsurface environment, but the overall flux of gas may be controlled by processes occurring deeper in the sediment. In this paper we explore the processes which retain gas beneath seal horizons and how such seals at different depths may leak. In doing so, we will demonstrate that observations of leakage mechanisms made in the upper few metres to tens of metres of sediment are not directly applicable to processes occurring deeper down, but that observed net surface fluxes can be understood in this way. In order to understand surface flux rates we frequently have to understand the rates of supply of gas from an accumulation at depth.
Seals and seal failure

A seal is a barrier to petroleum movement, either upwards or laterally, such as across faults. Here we will be concerned only with vertical movement, although the same concepts can be applied to fault gouges in order to understand lateral sealing also (see for example Watts, 1987).

Petroleum moves because a driving force causes it to. Buoyancy is the main driving force in most situations, sometimes influenced by overpressure (pressures above hydrostatic), and hydrodynamics. The force opposing this is the capillary resistance of the seal; petroleum must be forced through the narrow pore throats between grains. The smaller the pore throats, the greater the resistance to petroleum flow, and the more effective the seal.

A seal may be breached in one of two ways:

1. Capillary failure, where the driving force exceeds the capillary resistance to flow.

2. Fracture failure, where the driving force is sufficient to fracture the rock.

Capillary failure is the normal mode of failure under hydrostatic or moderately overpressured conditions; fracture failure generally occurs only in highly overpressured 


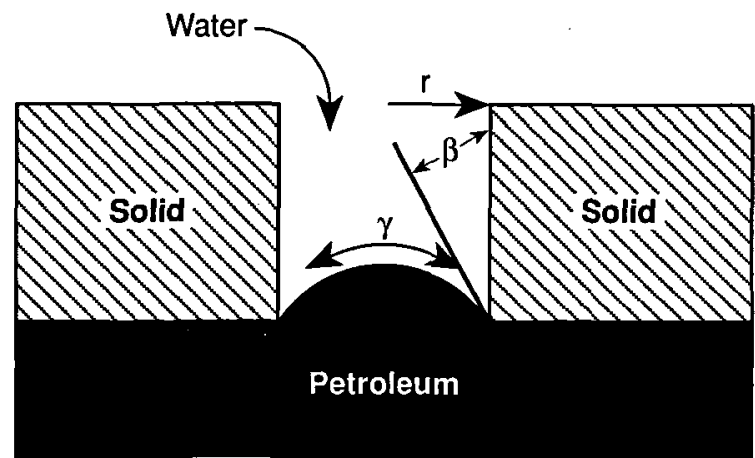

Fig. 1. Definition of terms referred to in capillary resistance calculations (equation 2).

environments or at shallow depths. It is relevant to look in more detail at these two failure mechanisms.

\section{Capillary failure}

The buoyant driving force $\left(\mathrm{P}_{\text {buoy }}\right)$ leading to seal failure is a function of the subsurface density contrast between petroleum and water, and the height of petroleum column or stringer:

$P_{\text {buay }}=\left(\rho_{w}-\rho_{p}\right)$ gh

in which $\rho_{w}$ and $\rho_{p}$ are the subsurface densities of water and petroleum respectively, $g$ is acceleration due to gravity $\left(9.81 \mathrm{~m} / \mathrm{s}^{2}\right)$ and $h$ is the height of the petroleum column. The units of this are Pascals $(\mathrm{Pa})$, which are usually quoted as kilopascals or megapascals $(1 \mathrm{MPa}=$ $10^{6} \mathrm{~Pa} \approx 145 \mathrm{psi}$ ).

The capillary resistance pressure $\left(\mathrm{P}_{\text {cap }}\right)$ depends on the difference in size between the pore throats in the reservoir and the seal, the interfacial tension between the petroleum and water, and the angle of contact of the petroleum-water interface against the adjacent rock grains (Fig. 1):

$\mathrm{P}_{\text {cap }}=2 \gamma\left(\frac{1}{\mathrm{r}_{\mathrm{s}}}-\frac{1}{\mathrm{r}_{\mathrm{r}}}\right) \cos \beta$

in which $\gamma$ is the interfacial tension, $r_{s}$ and $r_{r}$ are the pore throat radii of the seal and reservoir respectively, and $\beta$ is the contact angle. In practice, if the seal is water wet when failure occurs then the contact angle can be assumed to be $0^{\circ}$ so $\cos \beta$ becomes unity. Also, $r_{r}$ is generally much greater than $r_{s}$ so eq. 2 simplifies to:

$\mathrm{P}_{\mathrm{cap}} \approx\left(\frac{2 \gamma}{\mathrm{r}_{\mathrm{s}}}\right) \cos \beta$

For failure to occur, the upward buoyancy pressure plus any excess overpressure in the reservoir relative to the seal $(\Delta \mathrm{U})$ must exceed the capillary resistance:

$\mathrm{P}_{\text {buoy }}+\Delta \mathrm{U}>\mathrm{P}_{\text {cap }}$

or:

$\left(\rho_{w}-\rho_{p}\right) g h+\Delta U>\left(\frac{2 \gamma}{r_{s}}\right) \cos \beta$

This equation can then be rearranged to calculate the maximum petroleum column height which a seal can hold back:

$h=\frac{2 \gamma \cos \beta}{r_{s}\left(\rho_{w}-\rho_{p}\right) g}-\frac{\Delta U}{\left(\rho_{w}-\rho_{p}\right) g}$

In essence, the first part of the right hand side of this equation gives the normal column height which can be expected, and the second part gives a correction for excess overpressure in the reservoir. There are also two additional, and less obvious, conclusions we can draw from this equation:

1. If the migration path through the seal becomes oil-wet or gas-wet then the $2 \gamma \cos \beta$ term reduces, ultimately reaching zero. In other words, the resistance to flow approaches zero and the seal will continue to leak even after the column height drops below the critical value. This will only be the case if the petroleum stringer through the seal remains unbroken and in practice we do not know if this will occur or not, so this prediction remains untested.

2. There is no term for the thickness of the seal. Very thin seals, if continuous, are just as efficient as thick seals.

In order to evaluate equation [6] for the sealing of gas, we need to know how the densities of gas and water and the gas-water interfacial tension vary with depth, and to investigate the potential influence of both reservoir and seal overpressures. To do this we will take the basic case of the conditions given in table 1 and look at how the various parameters influence seal capacity.

Using appropiate figures for interfacial tension, typical pore throat radii for compacting shales, and subsurface fluid densities as defined in table 1 , we arrive at the seal

Table 1. Assumed initial conditions for column height calculations.

\begin{tabular}{lll}
\hline$\rho_{\text {water }}$ & $=1050 \mathrm{~kg} / \mathrm{m}^{3}$ \\
$\rho_{\text {oil }}$ & $=850 \mathrm{~kg} / \mathrm{m}^{3}\left(35^{\circ}\right.$ API) \\
$\rho_{\text {gas }}$ & $=0.76 \mathrm{~kg} / \mathrm{m}^{3}$ (at surface) \\
Pressure & $=$ based on $35 \mathrm{~m} / \mathrm{Ma}$ deposition rate \\
Seal & $=$ mudstone \\
$\gamma_{\text {oil-water }}$ & $=0.052 \mathrm{~N} / \mathrm{m}$ (at surface) \\
$\gamma_{\text {gas-water }}$ & $=0.076 \mathrm{~N} / \mathrm{m}$ (at surface) \\
Geothermal gradient & $=30^{\circ} \mathrm{C} / \mathrm{km}$ \\
Surface temperature & $=15^{\circ} \mathrm{C}$
\end{tabular}




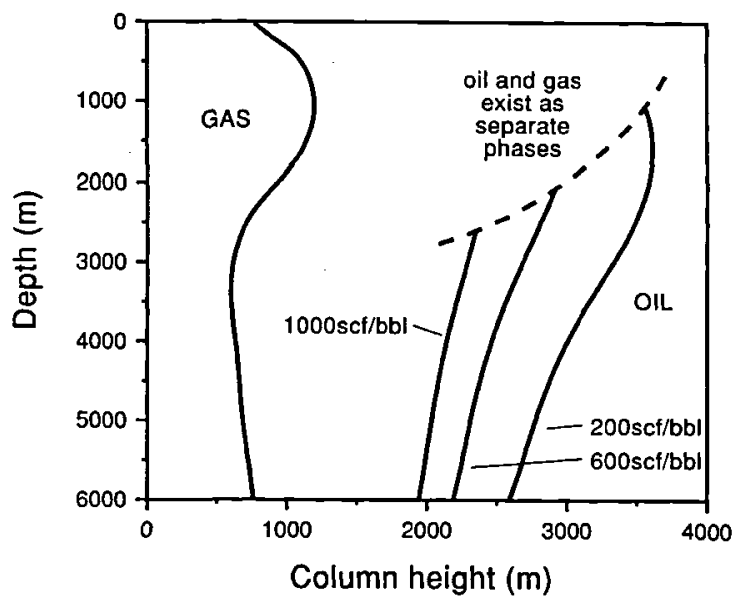

Fig. 2. Calculated seal capacity, expressed as column height supportable for dry methane and oil of varying Gas-Oil Ratio. Conditions as in table 1 .

capacity curve given in fig. 2 . The gas curve is for pure methane; with the addition of more wet gas components (i.e. ethane, propane $e t c$.) the gas curve would approach those shown for oil. Predicted gas columns supportable vary from about $500 \mathrm{~m}$ to $1000 \mathrm{~m}$ depending on depth, consistent with observed column heights for accumulations. However, note that the curves do not predict a simple downwards increase in seal capacity with depth as would be expected if we only considered the effects of shale compaction on the pore throat radius $r_{s}$. This is because both the interfacial tension and the density contast between the gas and water are also varying with depth so that the final curve is a combination of several non-linear trends. The increase in seal capacity between approximately 500 and $1500 \mathrm{~m}$ implies that gas should preferentially be ponded at these depths, as indeed is often observed during drilling operations.

We will now consider each of the variables in the seal capacity equation in turn in order to understand how these may vary from one geological environment to another.

The pore throat radius

This is the most important variable in the seal capacity calculation. It is also the most difficult to estimate. Part of the problem is simply to understand what we mean by the pore throat radius. Petroleum entering the seal will not flow through all of the pores in the rock but will seek out the largest interconnected pores and take the easiest route. The capillary resistance force will therefore be a function of the smallest pore throat encountered on this interconnected pore network. It will be neither the largest nor the smallest pore throats in the rock.

The pore throat radius can be measured by the technique of mercury injection porosimetry (Schowalter, 1979). This mimics invasion of the rock pores using high pressure mercury in the laboratory. A small rock chip (a few grams) from a side-wall or conventional core is dried then placed in a high pressure cell. The volume of mercury entering the sample is recorded as a function of pressure. Because both the interfacial tension and the mercury-air contact angle are known, the pore throat radius at a given pressure can be calculated from a rearranged version of equation [3]. The mercury injection curve is of course continuous over several orders of

Table 2. Measured pore throat radii from typical lithologies.

\begin{tabular}{|c|c|c|c|c|}
\hline \multirow[t]{2}{*}{ Area } & \multicolumn{2}{|l|}{ Sample details } & \multirow[t]{2}{*}{ Lithology } & \multirow{2}{*}{$\begin{array}{l}\text { Pore radius } \\
(\AA)\end{array}$} \\
\hline & Well & Depth (m) & & \\
\hline UKCS & $23 / 22 \mathrm{~A}$ & 2300 & mudstone & 125 \\
\hline $\begin{array}{l}\text { Offshore } \\
\text { Holland }\end{array}$ & $\begin{array}{l}\text { Ameland-1 } \\
\text { Ameland-1 } \\
\text { Terschelling-1 } \\
\text { Terschelling-1 } \\
\text { M/9-1 } \\
\text { M/9-1 }\end{array}$ & $\begin{array}{l}3563 \\
3570 \\
2721 \\
2794 \\
3304 \\
3332\end{array}$ & $\begin{array}{l}\text { mudstone } \\
\text { mudstone } \\
\text { mudstone } \\
\text { siltstone } \\
\text { mudstone } \\
\text { mudstone }\end{array}$ & $\begin{array}{r}150 \\
80 \\
140 \\
600 \\
480 \\
485\end{array}$ \\
\hline $\begin{array}{l}\text { Haltenbanken } \\
\text { Norway }\end{array}$ & $\begin{array}{l}6507 / 10-1 \\
6407 / 2-1 \\
6407 / 2-1\end{array}$ & $\begin{array}{l}3074 \\
3081 \\
3099\end{array}$ & $\begin{array}{l}\text { mudstone } \\
\text { siltstone } \\
\text { silty mud }\end{array}$ & $\begin{array}{l}100 \\
21,000 \\
950\end{array}$ \\
\hline $\begin{array}{l}\text { Western } \\
\text { Canada Basin }\end{array}$ & $\begin{array}{l}6-9-37-24 \\
\text { W4 (Mikwan) }\end{array}$ & $\begin{array}{l}2033 \\
2033\end{array}$ & $\begin{array}{l}\text { mudstone } \\
\text { silty mud }\end{array}$ & $\begin{array}{l}200 \\
1,500\end{array}$ \\
\hline $\begin{array}{l}\text { Dorset } \\
\text { UK }\end{array}$ & $\begin{array}{l}\text { Blue Lias } \\
\text { Blue Lias } \\
\text { Belemnite Marls } \\
\text { Eype Clay } \\
\text { Downcliff Clay } \\
\text { Fullers Earth }\end{array}$ & $\begin{array}{l}\text { outcrop } \\
\text { outcrop } \\
\text { outcrop } \\
\text { outcrop } \\
\text { outcrop } \\
\text { outcrop }\end{array}$ & $\begin{array}{l}\text { limestone } \\
\text { mudstone } \\
\text { mudstone } \\
\text { mudstone } \\
\text { mudstone } \\
\text { mudstone }\end{array}$ & $\begin{array}{l}280 \\
110 \\
120 \\
230 \\
160 \\
100\end{array}$ \\
\hline
\end{tabular}




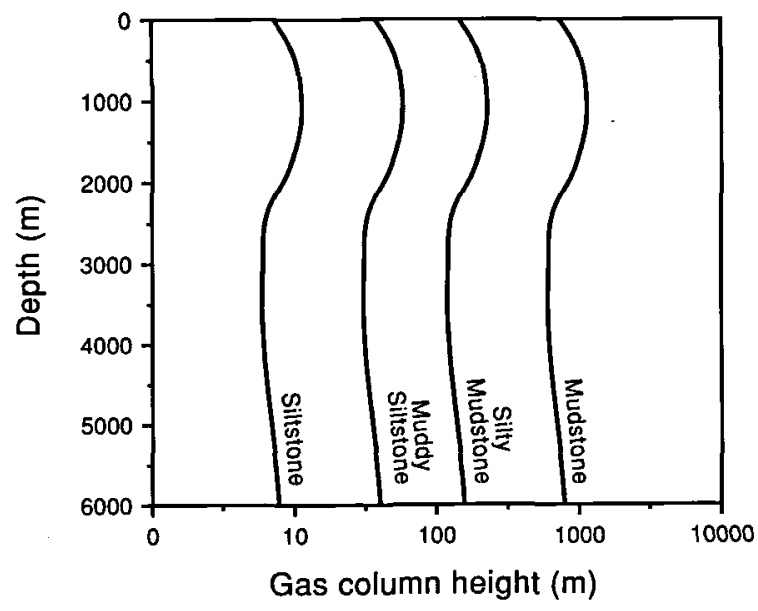

Fig. 3. Effect of different lithologies on seal capacity for dry methane.

magnitude of pore size, but a reasonable estimate of the value to use in equation [6] can be gained by taking the pore radius at $10 \%$ intrusion, the minimum for which the pores can be considered to be interconnected.
The pore throat radii of a number of mudstones and siltstones are given in table 2 and the seal capacity curves for typical seal lithologies are computed in fig. 3. Not surprisingly mudstones make better seals than siltstones because of their finer grain size. However, even a small increase in average grain size can cause a dramatic drop in seal capacity. A few very fine grained rocks will totally dominate the migration route of petroleum seeping to the surface.

\section{Interfacial tension}

The methane-water interfacial tension at elevated temperatures and pressures has been determined in the laboratory by Hough, Rzasa \& Wood (1951), and these data are reproduced here in fig. 4 after an appropiate change of units. At surface conditions pure methane has a value of about $0.076 \mathrm{~N} / \mathrm{m}$. This value will approach that of oil as the $\mathrm{C}_{2+}$ content of the gas increases. Interfacial tension is affected by both temperature and pressure and taking typical geothermal and geobaric gradients results in the broken curve shown in fig. 4 . In practice, even extreme variations in temperature and pressure profiles will have little effect on the seal capacity.

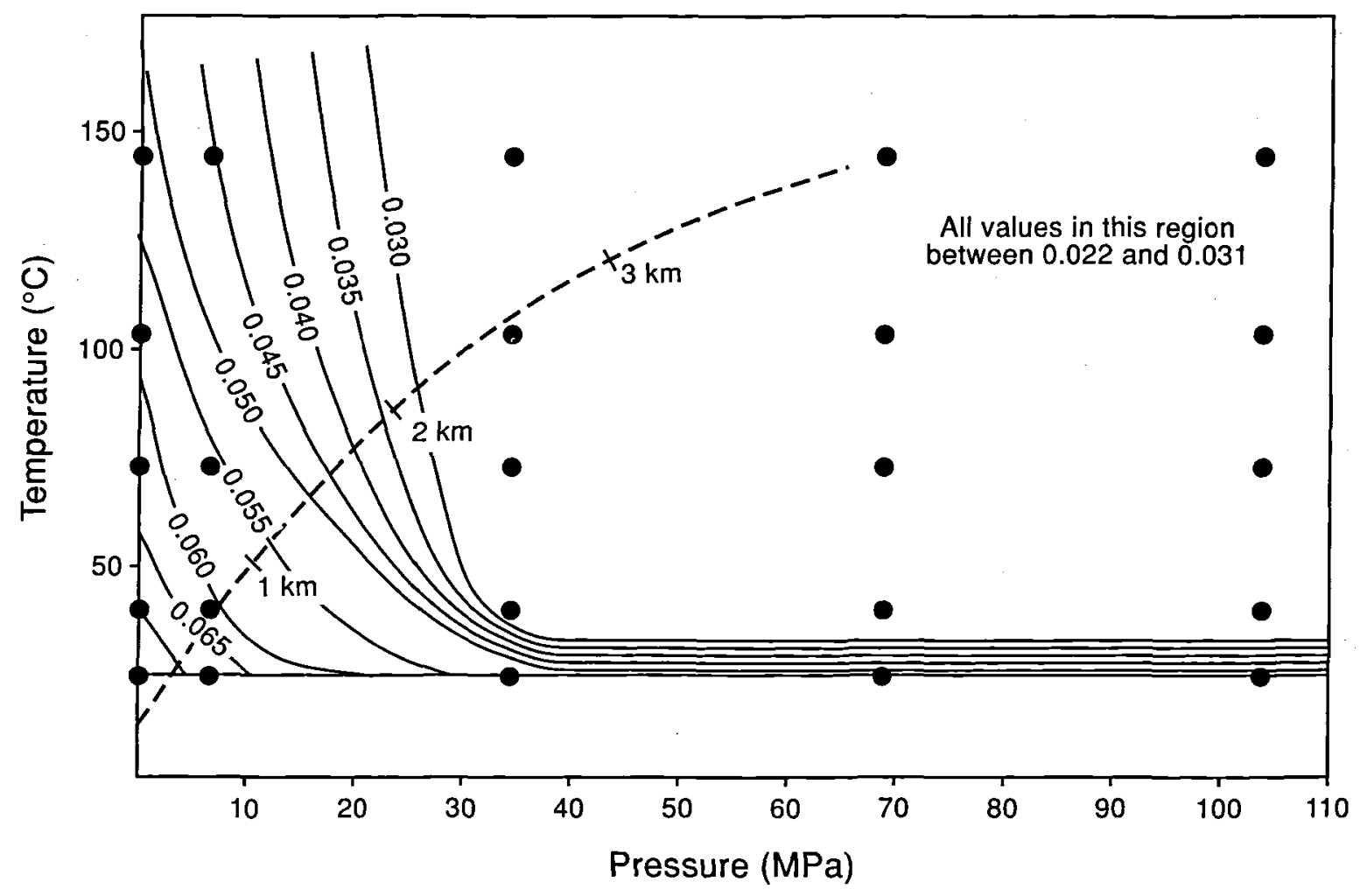

Fig. 4. Gas-water interfacial tension at elevated temperature and pressure (after Hough et al. (1951), reported in Schowalter, 1979). Broken line corresponds to the interfacial tension at different depths for the case described in table 1. 


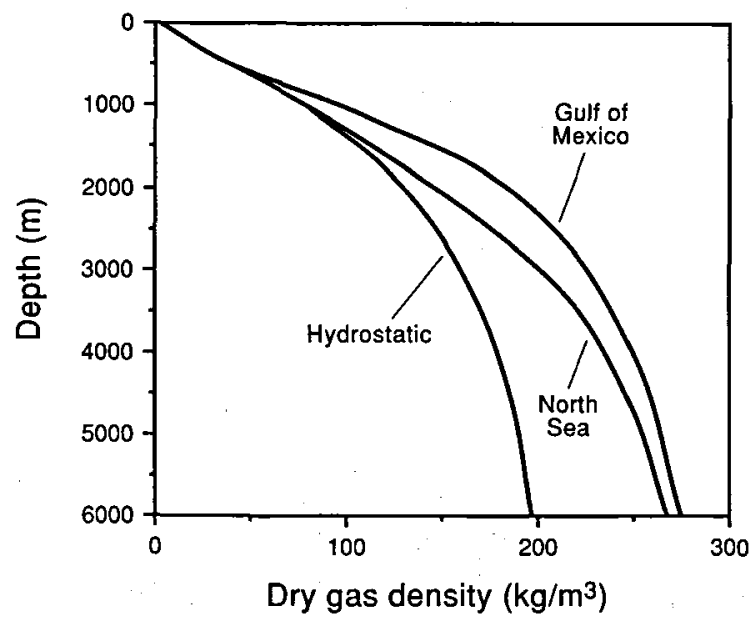

Fig. 5. Dry gas density versus depth for different pressure regimes. "North Sea" refers to pressure profile expected for 35 $\mathrm{m} / \mathrm{Ma}$ based on the pressure model of Mann \& Mackenzie (1990), "Gulf of Mexico" is the comparable curve for 1000 $\mathrm{m} / \mathrm{Ma}$.

\section{Petroleum Buoyancy}

The buoyancy term in equation [6] depends on the subsurface density of both petroleum and water. The subsurface density of gas is very sensitive to pressure and ultimately approaches that of oil as pressure increases and the oil/water system becomes supercritical. Typical depth-density curves for pure methane are given in fig. 5 , based on hydrostatic conditions and typical pressures expected for North Sea and Gulf of Mexico sedimentation rates (approximately 35 and $1000 \mathrm{~m} / \mathrm{Ma}$ respectively).

For typical sedimentary basins, dissolved solids vary

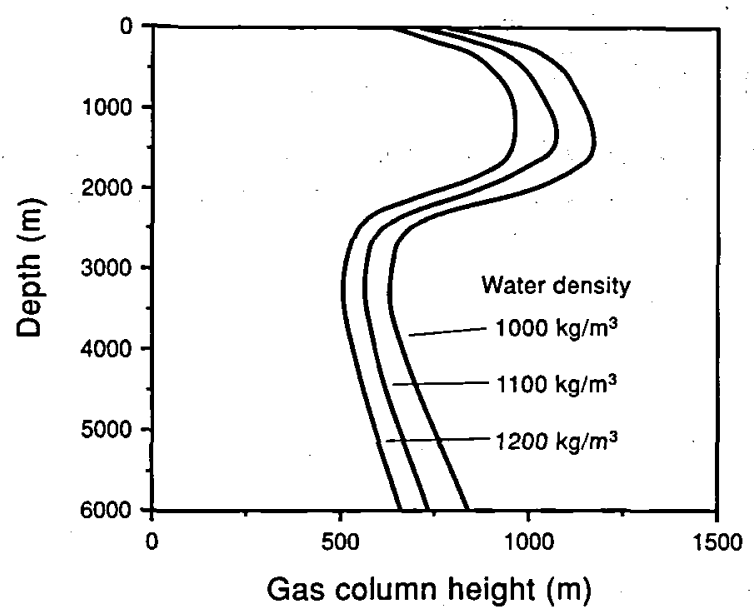

Fig. 6. Effect of subsurface water density on seal capacity.

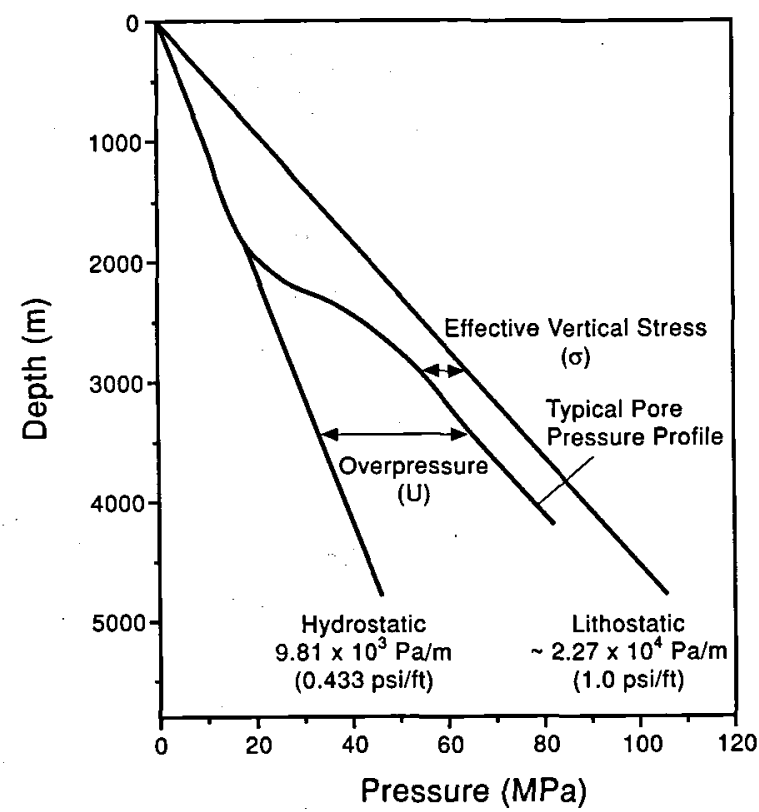

Fig. 7. Definition of pressure terms used in text.

up to about $200,000 \mathrm{ppm}$ resulting in water densities under reservoir conditions of roughly between 1000 and $1120 \mathrm{~kg} / \mathrm{m}^{3}$ (Schowalter, 1979). In rare cases (notably some salt basins) salinities may reach up to $400,000 \mathrm{ppm}$ with corresponding densities up to $1200 \mathrm{~kg} / \mathrm{m}^{3}$. Taking the gas density curve and typical water densities results in the family of curves shown in fig. 6. The effects of different waters are fairly subtle, with even the highest water density giving only a $20 \%$ reduction in seal capacity relative to fresh water.

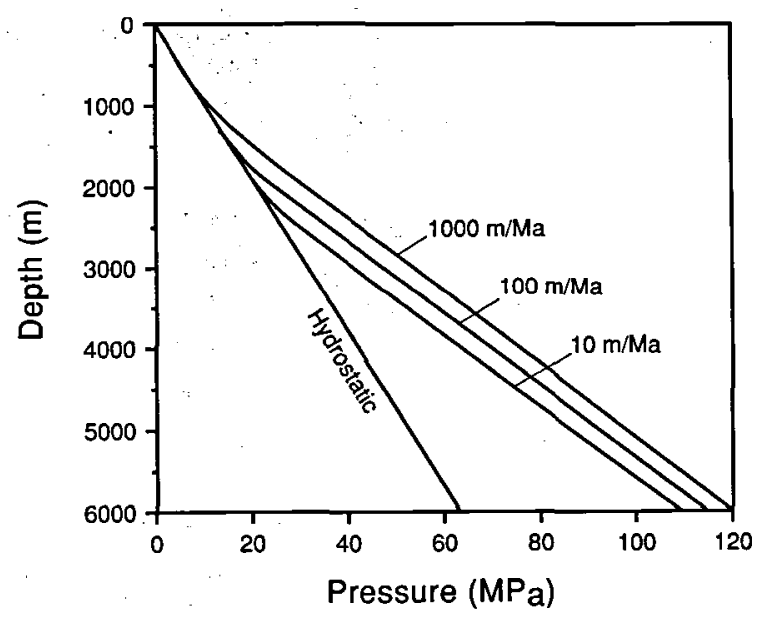

Fig. 8. Effect of variable deposition rate on subsurface pressurure profiles, as computed with the Mann \& Mackenzie (1990) model.

Bulletin of the Geological Society of Denmark 


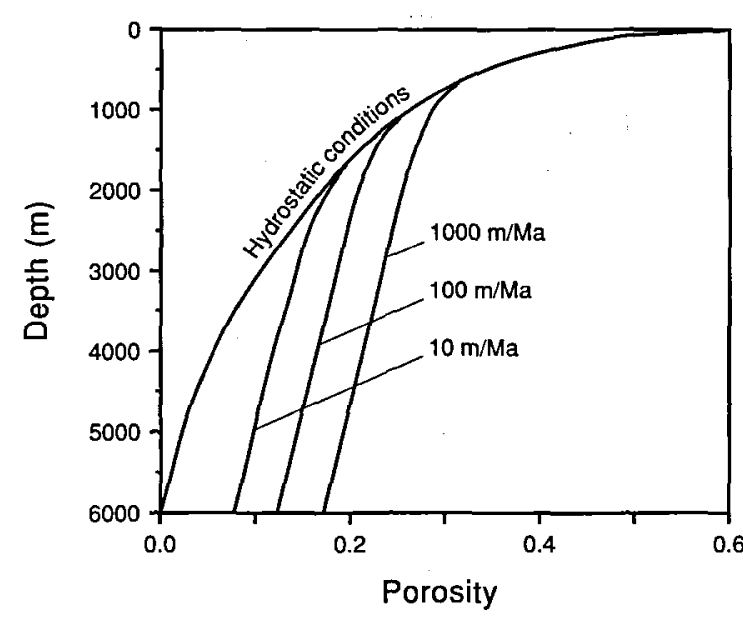

Fig. 9. Modelled effect of deposition rate on mudstone porosity according to the Mann \& Mackenzie (1990) model.

\section{Overpressure}

The term "overpressure" refers to pressures above hydrostatic; the pressure expected for a continuous water column through the entire depth of the sediment. (In essence, this assumes that all the pores in the sediment pile are interconnected.) In most sediments the pore fluid pressures are greater than this (see fig. 7), sometimes approaching the lithostatic gradient, equivalent to the weight of the overlying rock mass. Overpressuring has two distinct and substantial influences on seal effectiveness. Firstly, any overpressure in a mudrock will inhibit compaction resulting in higher. porosities, larger pore throats and hence lower seal efficiency at any given depth. Secondly, differences in overpressure between the

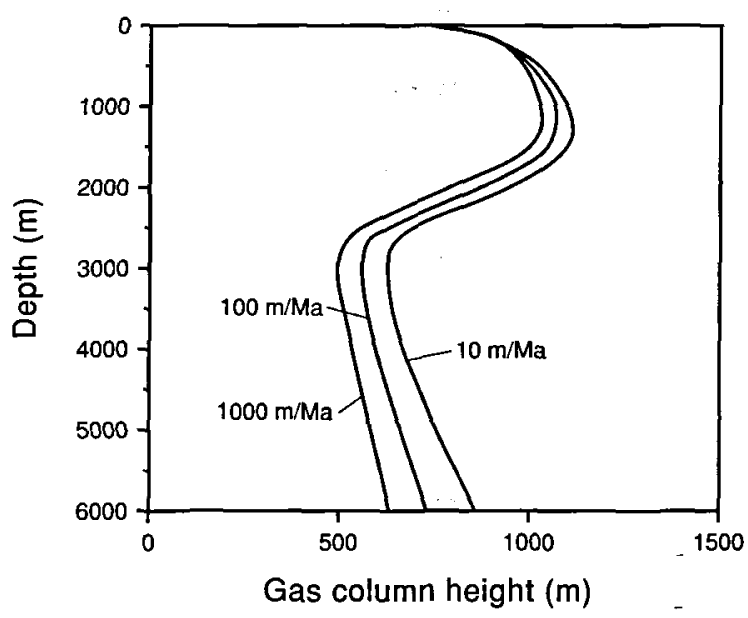

Fig. 10. Effect of variable deposition rate on seal capacity. Higher sedimentation rates result in higher overpressure, hence higher pore throat radii and lower seal capacity. reservoir and the overlying seal will affect the critical balance between buoyancy and capillary resistance. This can either increase or dramatically decrease seal efficiency depending on the circumstances.

Considering the first of these, fig. 8 shows how overpressure depends on sedimentation rate. Overpressure is dominantly the result of "compaction disequilibrium", in which overpressure builds up because the permeability of the rock is too low to allow dewatering to occur fast enough to keep pace with the increasing sediment load (Mann \& Mackenzie, 1990). Higher deposition rates result in higher overpressures. The effect of this on porosity is shown in fig. 9, and the resulting influence on seal capacity in fig. 10. Although not a great effect, we should expect to see differences in the "leakiness" of different sedimentary basins with different sedimentation rates. For example the deep water Gulf of Mexico, where sedimentation rates in the Plio-Pleistocene can exceed 1000 $\mathrm{m} / \mathrm{Ma}$ should be significantly more leaky than the North Sea with an average Tertiary deposition rates of $35 \mathrm{~m} / \mathrm{Ma}$.

Turning to the influence of differential overpressure between reservoir and caprock, we recall from equation [6] that any excess overpressure in the reservoir will decrease seal efficiency (and vice versa). In effect the high pressure water acts like a piston, forcing the petroleum through the seal. Such differences in overpressure result from equilibration of overpressure in tilted aquifers; overpressure is effectively transported up-dip in the high permeability beds. At the deep end of the reservoir, overpressure will be less than in the overlying shale but at the updip end it will be greater (Fig. 11). Such situations are very widespread in sedimentary basins and so this situation is very common.

Taking the case of the up-dip end of a tilted reservoir, which is the most common for petroleum accumulations, fig. 12 shows the effect of excess pressure on seal effectiveness. At only reasonable overpressures ( $c a$. $10 \mathrm{MPa}$, $\approx 1500$ psi) the seal capacity is reduced to zero. In other words, all fields with this degree of overpressure will leak, even though the pressure may not be high enough to fracture the seal. This situation will be very common in natural sedimentary basins. In contrast, the seal capacity will be enhanced at the down-dip end of the reservoir.

If nearly all such up-dip fields leak, this of course begs the question why so much petroleum is still trapped. Obviously we need to consider the rates at which leakage can occur rather than just the static system. We will return to this point below.

\section{Fracture Failure}

Failure of seals by fracturing will occur when the pore fluid pressure (induced by overpressuring and petroleum buoyancy) exceeds the local rock strength and the tensile strength holding the rock together:

$P_{p}>S+T_{s}$ 


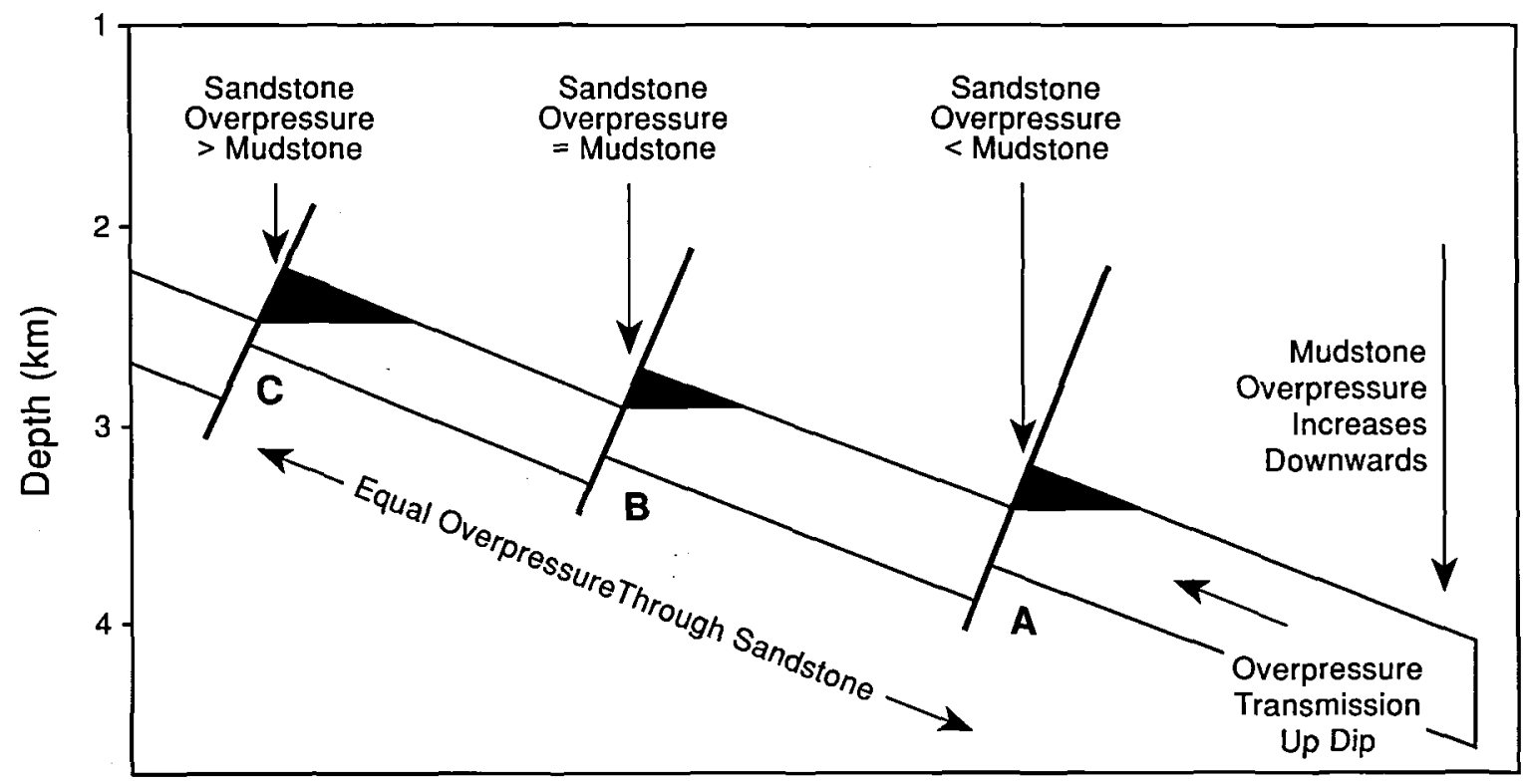

Fig. 11. Principle of up-dip overpressure transmission in highly permeable beds enclosed in mudstone. At the shallow end of the reservoir, overpressures are anomalously high compared to the enclosing mudstone. At depth they are anomalously low.

in which $P_{\mathrm{p}}$ is the pore fluid pressure, $S$ is the total stress and $T_{s}$ is the tensile strength of the rock. Mudrocks are very weak under subsurface conditions so we can effectively ignore the tensile strength as insignificant.

It is often more convenient to think in terms of the effective stress, $\sigma$, which is the difference between the total stress pushing the rock together and the pore fluid pressure pushing it apart again:

$\sigma=\left(\mathrm{S}-\mathrm{P}_{\mathrm{p}}\right)$

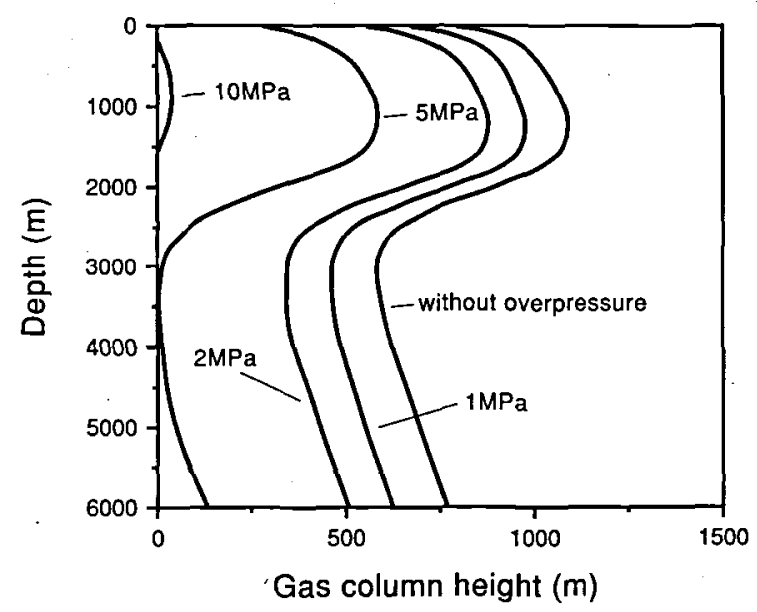

Fig. 12. Effect on seal capacity of excess overpressure in the reservoir compared to that in the seal.
The rock will fracture when the effective stress becomes zero. Fractures will form perpendicular to the minimum

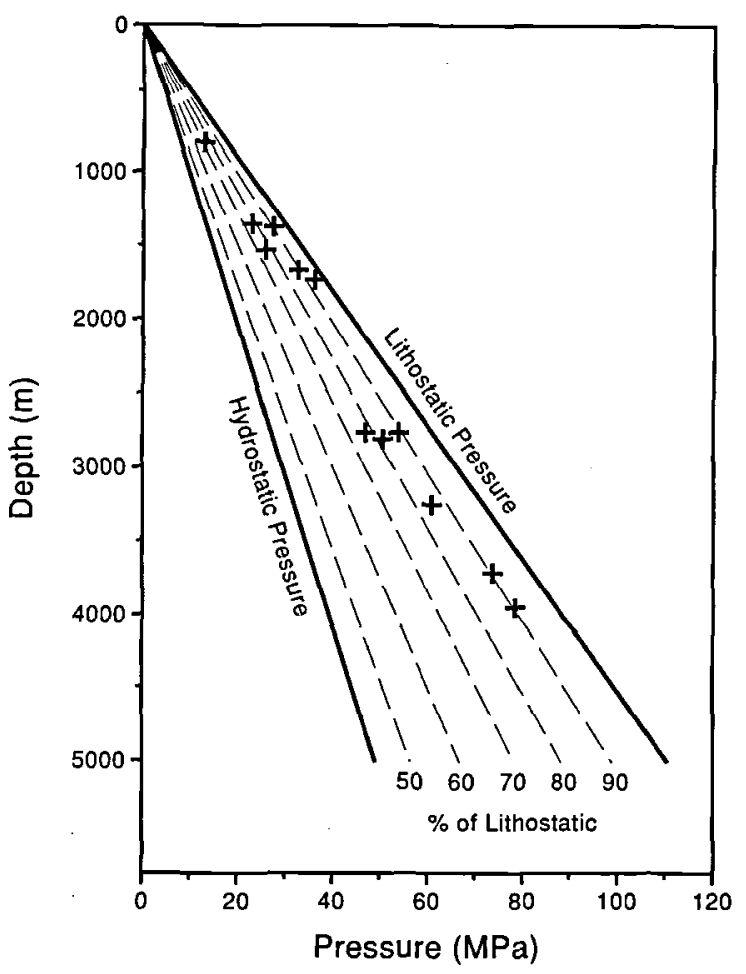

Fig. 13. Cap rock leak-off pressures for North Sea oil and gas condensate fields.

Bulletin of the Geological Society of Denmark 


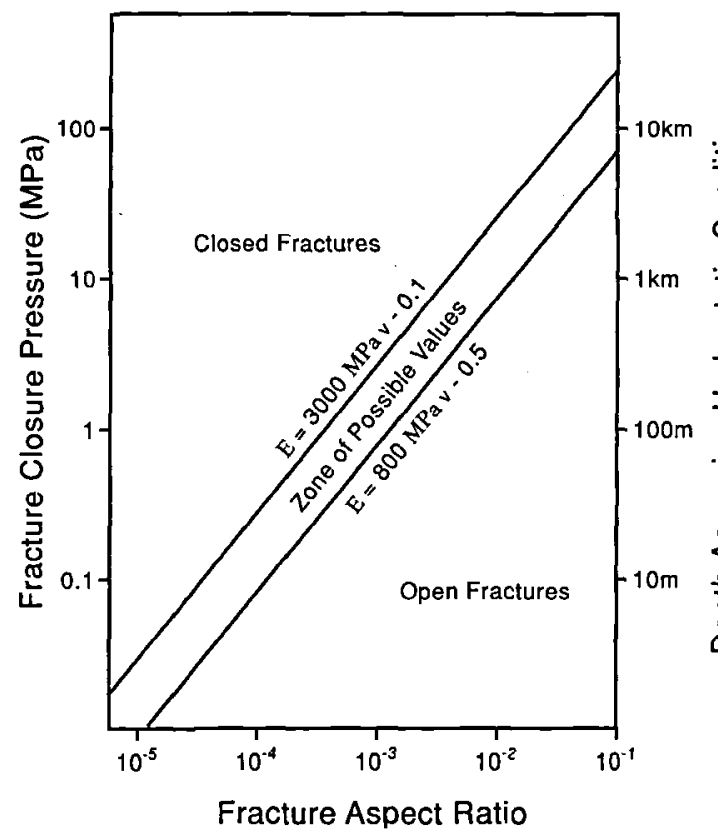

Fig. 14. Calculated fracture closure pressure in mudstones as a function of fracture aspect ratio (width divided by length of fracture), Young's modulus (E) and Poisson's ratio (v). Equivalent depth is based on hydrostatic conditions.

effective stress $\left(\sigma_{3}\right)$ direction. Usually $\sigma_{3}$ is horizontal, so vertical fractures will form. We therefore need to estimate the minimum horizontal stress in order to predict fracture failure.

If well data are available then the pressure required for fracturing can be estimated from leak-off tests. These are carried out by drillers to determine the maximum weight of drilling mud which a formation can withstand without losing circulation (i.e. fracturing). The well is extended a little beyond the casing and the pressure on the drilling mud is increased until fluid loss is observed. The pump is then stopped and the well left until enough fluid has leaked to balance the minimum stress and close the fracture. The pressure of the drilling mud then gives the minimum pressure required for fracturing of the formation.

Figure 13 shows a collation of leak off pressures for mudstone seals to North Sea oil and gas condensate accumulations. Fracturing generally occurs at between 80 and $95 \%$ of lithostatic pressure. This can be rationalised when one considers the relationship between the minimum effective horizontal stress $\left(\sigma_{3}\right)$ and the vertical effective stress $\left(\sigma_{1}\right)$. In a tectonically relaxed basin, these two are related by Poisson's ratio (v), an index of rock stiffness (Eaton, 1969): $\sigma_{3}=\left[\frac{v}{1-v}\right] \sigma_{1}$

The maximum effective stress, $\sigma_{1}$, is the overburden stress, $S_{1}$, minus the pore fluid pressure in the seal:

$\sigma_{1}=\left(S_{1}-P_{\text {seal }}\right)$

and the minimum effective stress is the minimum total stress $\left(S_{3}\right)$ minus the pore fluid pressure:

$\sigma_{3}=\left(S_{3}-P_{\text {seal }}\right)$

hence combining equations 9,10 and 11 we find the minimum stress required to cause fracturing in the seal:

$\mathrm{S}_{3}>\left[\frac{v}{1-v}\right]\left(\mathrm{S}_{1}-\mathrm{P}_{\text {seal }}\right)+\mathrm{P}_{\text {seal }}$

For the case here, $S_{3}$ corresponds to the reservoir pressure immediately below the seal, and $S_{1}$ is the overburden (lithostatic) pressure. Poisson's ratio for uncemented shales is generally in the order of 0.4 to 0.5 (i.e. they are very soft) hence in the limiting case of a hydrostatically pressured seal, the horizontal confining pressure resisting fracturing is in the order of $83-100 \%$ of lithostatic pressure. If the seal itself is overpressured, then this increases. In the extreme, as seal pressure approaches lithostatic, then so too does the pressure required in the reservoir to initiate fractures. In this case $\sigma_{1}=\sigma_{3}$ and fractures will form in random orientation.

\section{Pre-existing fractures and faults}

Fractures, when formed, will remain open only as long as sufficiently high pore fluid pressures are maintained. This is illustrated in fig. 14, which shows the closure pressure required to re-seal fractures once they are formed (based on the work of Walsh, 1965). Natural fractures typically have an aspect ratio (the ratio of width to length) in the range of $10^{-5}$ to $10^{-2}$. Even in very inelastic rocks (high Young's modulus, E, and low Poisson's ratio, $v$ ) only 10 $\mathrm{MPa}$ are required to close even the fattest (large aspect ratio) fractures. This correspond to only $1 \mathrm{~km}$ of burial at most, and only a few hundred metres or so for the majority of fractures which have aspect ratios less that $10^{-3}$. Thus fractures in mudrocks have little effect on petroleum migration except in the upper few hundred metres of sediment, or unless propped open by pore fluid pressures approaching lithostatic.

The same thing is true for faults, as long as the fault plane does not juxtapose sand against sand. Morrow et al. (1934) have published permeabilities for fault gouges in a number of lithologies. At the confining pressures associated with typical gas accumulations (up to $100 \mathrm{MPa}$ ) permeabilities range from a little below $10^{-18}$ to $10^{-21} \mathrm{~m}^{2}$. This is comparable to measured permeabilities in typical 


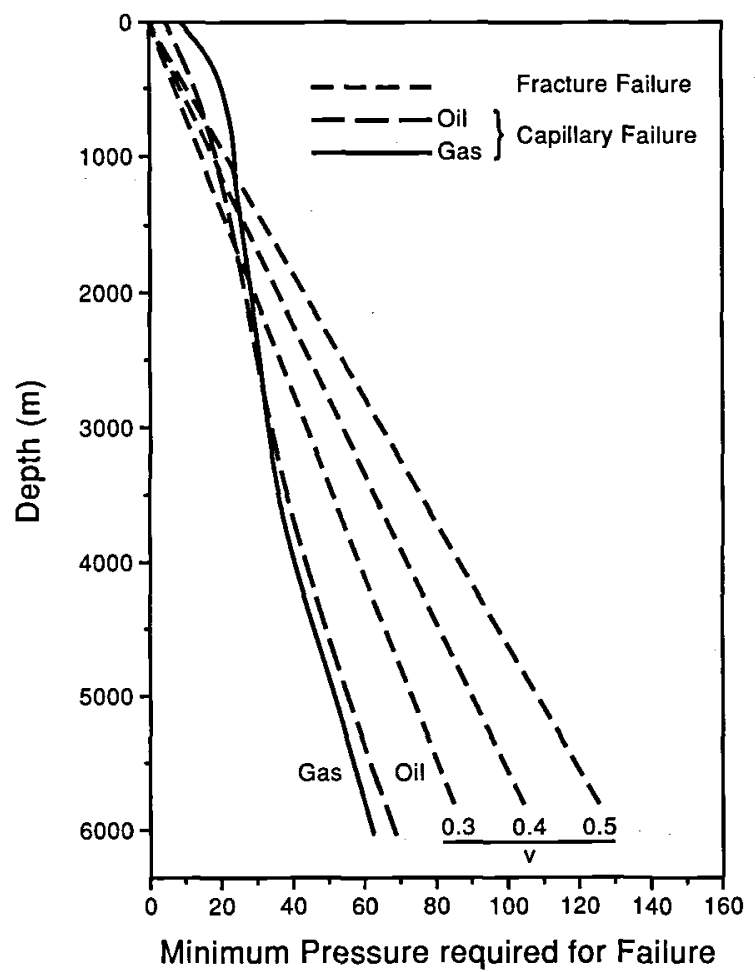

(MPa)

Fig. 15. Minimum pressure required for seal breakdown by fracture failure for different Poisson's ratio $(v)$ and by capillary failure. Near the surface fractures are most likely to form, but at depths below about $1500 \mathrm{~m}$ capillary failure will occur first.

mudrocks. However, if the fault is currently active then flow may occur transiently, associated with seismic pumping, of during the period of closure of irregularities in the fault plane following movement. This is why Thrasher et al. (unpublished) observed seepage along active fault planes while buried faults acted as seals.

\section{Capillary Failure or Fracture Failure?}

Predicting if seal failure will occur by capillary failure or by fracturing is a relatively simple procedure. All that is requircd is to estimate the pressure required for both types of failure. Whichever is the lower will be the process which occurs first.

Figure 15 illustrates a combination of the capillary and fracture failure data presented above. The horizontal axis gives the minimum reservoir pressure required to cause failure for each mechanism. The pressure is derived from the petroleum buoyancy and the excess overpressure in the reservoir relative to the seal, in any combination (i.e. higher overpressures require lower petroleum column heights to initiate failure). Conditions are as given in table 1 .

It can be seen that in the upper few hundred metres fracturing will occur preferentially to capillary failure. In this zone other processes may also be active, such as mud diapirism (Hovland \& Curzi, 1989). Below about $1500 \mathrm{~m}$ however fractures become less important. The pressure required for capillary failure is always less than that for fracturing. In other words, seals at depth will always fail by capillary leakage before they fracture, so that the observation of seepage from fractures at the surface does not imply that migration is fracture-dependent below the surface zone. This does not mean that fracturing cannot occur at depth however. If the pressure continues to increase after capillary failure occurs then the seal may still fracture some time later.

Note also that there will be a tendency for gas, rather than oil, to pond in the shallow subsurface $(<1500 \mathrm{~m})$ as is indeed the observed case; it is common to encounter shallow gas pockets during drilling, but fairly unusual to find shallow oil pools.

These predictions are borne out by observations from the North Sea. Figure 16 is a plot of reservoir pressure versus depth for North Sea oil and gas condensate fields which are known to be leaking from seismic evidence (gas blanking, phase inversions, velocity pull down etc.) In almost all cases the seals have failed at pressures significantly below that required for fracture failure of the top seal (taken as $80 \%$ of lithostatic pressure in this figure). We conclude that capillary failure is widespread, and that many, if not most surface gas seeps are probably controlled by this process.

\section{Rates of Trap Leakage}

We now address the problem of how fast petroleum can escape from the structure for both capillary failure and the less common fracture failure. It is not possible to measure this directly so the best we can do is to make order of magnitude estimates from simple fluid dynamic considerations.

We take as our starting point the Darcy equation of fluid flow. This relates the rate of fluid flow to the driving force or "potential gradient" $(\nabla \Phi)$, the permeability of the rock $(k)$, and the fluid viscosity $(\mu)$ :

$\mathrm{q}=\frac{\mathrm{k}}{\mu} \nabla \Phi$

$q$ is equivalent to the rate of advance of the seeping petroleum front following initial failure. The Darcy equation is probably more familiar in the form of a flux (Q) per unit area with dimensions of $\mathrm{m}^{3} / \mathrm{m}^{2} / \mathrm{s}$.

\section{Capillary Flow Rates}

For capillary failure, the intrinsic permeability, $k$, can be related to the pore throat radius, $r$, and the porosity, $\phi$, by assuming Poiseuille flow. This is flow through a con- 


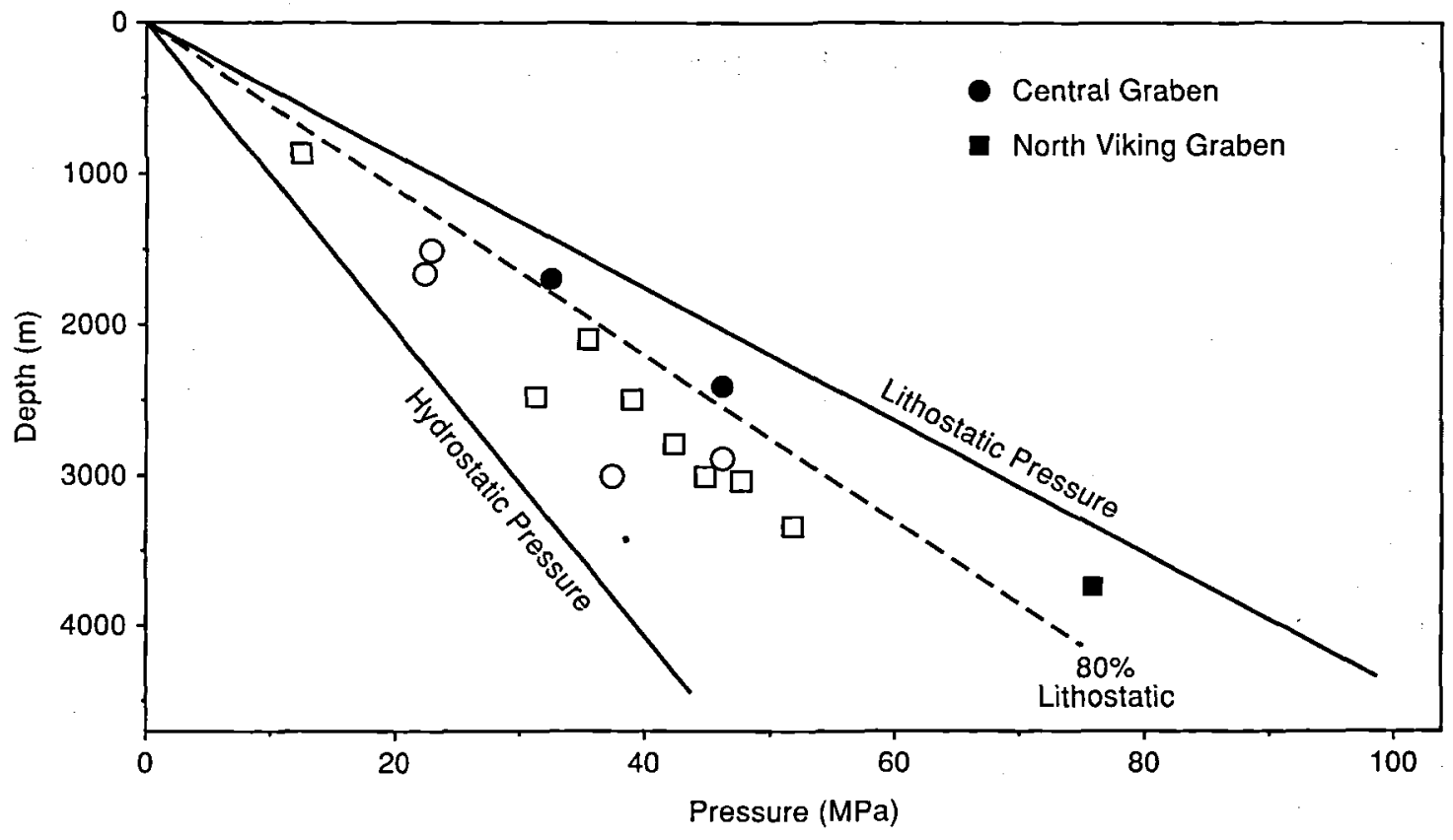

Fig. 16. Reservoir pressures for North Sea oil and gas condensate fields thought to be leaking based on seismic indications. Note that the majority of fields (shown as open symbols) are leaking at pressures below $80 \%$ of lithostatic pressure (approximately that required for fracturing) indicating capillary failure of the seal.

torted network of pores characterised by a tortuosity factor $\theta$ (the ratio of actual path length travelled through the rock pore network to the direct path length). It is more appropiate to use this approach rather than measured permeabilities in water-wet rocks since the latter are biased by the presence of clay-bound water which results in anomalously low apparent permeabilities (Honda and Magara, 1982). Under the conditions of Poiseuille flow:

$\mathrm{k}=\frac{\phi \mathrm{r}^{2}}{8 \theta^{2}}$

It is usual to take $\theta$ as $\sqrt{3}$, the theoretical value assuming loosely packed spherical rock grains. In practice the value of $\theta$ has comparatively little effect on the flow rate compared with the pore throat radius. In addition, because petroleum does not flow through all of the pores we have to add an additional correction (S) for the oil saturation of the rock. The saturation of oil migrating in a shale is not known but we can take a value of $0.1(10 \%$ saturation) to illustrate the point. This is probably the minimum necessary to create a continuous gas phase within the water-wet rock although it may be more valid to choose a higher value as recommended by England $e t$ al. (1987). Taking all this into account, our modified Darcy equation now becomes:

Clayton \& Hay: Gas migration mechanisms
$q=S \frac{\phi r^{2}}{8 \theta^{2} \mu} \nabla \Phi$

We will take as an example a mudstone seal at $3 \mathrm{~km}$ depth. Typically, this will have a porosity of about $17 \%$ (i.e. 0.17 ) corresponding to a pore throat radius of about $100 \AA\left(10^{-8} \mathrm{~m}\right)$. This gives a modelled permeability of about $7 \times 10^{-19} \mathrm{~m}^{2}$. Under North Sea geothermal and pressure gradients, gas at this depth will have a viscosity of about $3.10^{-5}$ Pas ( 0.03 centipoise). We will assume that the seal is $50 \mathrm{~m}$ thick, and that we have $1 \mathrm{MPa}$ excess driving force over that required to initiate capillary seal failure (itself about $6 \mathrm{MPa}$, giving an excess pressure in the reservoir of $7 \mathrm{MPa}$, or a little over $1000 \mathrm{psi}$, a value not atypical for the North Sea). This gives $\nabla \Phi$ of 20 $\mathrm{kPa} / \mathrm{m}$ and a corresponding flow rate, $\mathrm{q}$, of $4.72 \times 10^{-11}$ $\mathrm{m} / \mathrm{s}$, or just under $1500 \mathrm{~m} / \mathrm{Ma}$. The flux across the seal under these conditions is $0.0015 \mathrm{~m}^{3} / \mathrm{m}^{2} /$ year. If the area of seal over which leakage is taking place is, say $1 \mathrm{~km}^{2}$, then we will lose approximately $1,500 \mathrm{~m}^{3} /$ year, equivalent to roughly $7 \mathrm{tcf} / \mathrm{Ma}$ at surface conditions. Thus although just about all overpressured reservoirs will leak, even in the fairly extreme case used here the lifetime of a significant gas accumulation is still in the order of a million years or so, in less extreme cases it will be much greater.

This is of course a very simplified case. If for example a continuous gas phase was present through the seal after the initial breakthrough, then the capillary resistance 
would be eliminated, leading to increased flow rates. Conversely, as the reservoir empties, then the buoyant driving force will decrease leading to lower flow rates. Nevertheless, this simple calculation is sufficient to demonstrate that capillary leakage is an intrinsically slow process, even on geological time scales.

\section{Fracture Flow Rates}

For fractures, the flow rate depends on the width of the fracture and its shape. Taking the simple case of a smooth parallel-walled vertical fracture, the permeability can be described as a function of the fracture width (w)'and their spacing (Parsons, 1966):

$k_{\mathrm{fr}}=\frac{\mathrm{w}^{3}}{12 \mathrm{D}}$

where $\mathrm{D}$ is the fracture spacing in metres. For example a single fracture, $1 \mathrm{~m}$ long and $100 \mu \mathrm{m}$ wide, this corresponds to a permeability of $8.3 \times 10^{-14} \mathrm{~m}^{2}$, or five orders of magnitude greater than the capillary permeability in the above example. The fracture density for any breached seal is not known but is likely to be very high, thus we can expect fracture flow rates to be several orders of magnitude faster than capillary leakage rates.

This assumes that the fractures are continually open which is unlikely to be the case. In practice the fractures will open transiently to release the overpressure and then re-seal until the pressure builds up again. However, even if the fracture is open for an average of only one minute per year, this corresponds to the same net flow from a single fracture as for capillary failure. Gas accumulations at the point of fracture failure will have a very short lifetime indeed unless continually topped up.

\section{Predicted Surface Fluxes}

Based on the the above calculations, we can now derive an estimate of the gas fluxes which we can expect to see arriving at the surface as observable seeps. For capillary failure, the above example gave a flux of $0.0015 \mathrm{~m}^{3} / \mathrm{m}^{2} /$ year over the area of the seal which is leaking, equivalent to a surface volume of $0.23 \mathrm{~m}^{3} / \mathrm{m}^{2} /$ year. A similar flux would be expected for a fracture density of one $100 \mu \mathrm{m}$ fracture per metre assuming an average "open time" of 2 $\times 10^{-6}$ (equivalent to 1 minute/year) which is probably a severe underestimate. This assumes vertical transport and seepage over the same area of leakage through the top seal. Much leaking gas could of course be focussed along high permeability "thief" zones resulting in higher flux rates over a smaller area at the surface.

Few measurements of flux rates for gas seeps are available but we can consider two examples. In the Kattegat, Dando et al. (in press) estimate a flux of $59.4 \mathrm{ml} /$ $\mathrm{hr} / \mathrm{m}^{2}$ at atmospheric conditions, equivalent to $0.52 \mathrm{~m}^{3} /$ $\mathrm{m}^{2} /$ year. This is in very good agreement with the flux calculated above considering the assumptions made in the calculations and in the seepage flux estimates. For example, the two would be almost identical if we took a gas saturation of $20 \%$ rather than $10 \%$ in our capillary flux equation (eq. 15). Hovland and Sommerville (1985) studied gas seeps above the Ekofisk field in the North Sea. They reported a total flux for an area of $7800 \mathrm{~m}^{2}$ containing 120 seep vents of $24 \mathrm{~m}^{3} /$ day at ambient pressure in $75 \mathrm{~m}$ of water. Extrapolating this to the whole area in which seepage was observed (c. $100000 \mathrm{~m}^{2}, 140$ seeps) gives a total flux in the order of $0.102 \mathrm{~m}^{3} / \mathrm{m}^{2} /$ year at ambient conditions, or about $0.77 \mathrm{~m}^{3} / \mathrm{m}^{2} /$ year at atmospheric conditions. This is a little greater than for the Kattegat but still in very good agreement with the theoretical calculations. This suggests that capillary leakage of gas accumulations at depth, at least at these two localities, can account for the observed surface gas seepage rates without substantial focussing of flow during migration to the surface, or by invoking fractures.

The higher local flux rates from individual seep vents at the surface probably represent local fracturing of shallow gas pockets which are fed from below. The flux of gas from these appears to be in approximate equilibrium with the gas flux arriving from depth.

\section{Conclusions}

1) In sediments shallower than about $500 \mathrm{~m}$, cap rocks will be breached by fracturing rather than by capillary failure. Below about $1500 \mathrm{~m}$ capillary failure will always occur in preference. Thus the observation of seepage from fractures at the surface does not imply fractures at depth. 2) The curve of gas column supportable beneath a seal is not linear with depth. There is a tendency for gas to pond in shallow sediments, typically at about $1000 \mathrm{~m}$ depth. Below this, the column height supportable decreases dramatically, then increases again more slowly below about $2000 \mathrm{~m}$. 3) Below the upper few hundred metres, pre-existing fractures and inactive faults have little influence on gas migration. 4) Capillary failure of a seal leads to intrinsically slow flux rates of leaking gas. Fracture failure may lead to fluxes several orders of magnitude greater, but these are limited by the amount of time the fracture remains open. 5) The calculated leakage rates from capillary failure of a mudstone seal at $3 \mathrm{~km}$ depth are comparable with the few reported gas seepage fluxes recorded at the surface. This implies that surface fluxes are controlled ultimately by the rate of supply of gas from below. Leakage from shallower intermediate pockets of gas to the surface will control the local distribution of gas seeps only. 


\section{Acknowledgements}

We thank our many current and former colleages whose numerous discussions over the years have helped to shape this research. In particular we thank Dave Mann who wrote the pressure prediction model on which the subsurface pressure calculations were based, and Mike Lines who perfomed many of the calculations. We also thank $\mathrm{BP}$ for permission to publish this work.

\section{Dansk sammendrag}

Gasudsivning ved jordoverfladen, på land såvel som i det submarine miljø, opstår snarere som følge af lækage fra gas- og oliereservoirer $i$ dybereliggende strukturer end som følge af en kontinuerlig gasudsivning fra en moderbjergart. Det kan påvises, at mekanismerne ved gasmigration varierer med dybden. I dybet, dvs. mere end 500 $\mathrm{m}$ under jordoverfladen, vil gasmigrationen primært ske via det eksisterende porenetværk, mens der i de øverste få hundrede meter af lagsøjlen vil være en hyppigere tendens til opsprækning af bjergarten. Man skal derfor være opmærksom på, at det der ved den direkte observation af et gasudslip ser ud som værende en funktion af sprækkepermeabilitet primært styret af diffus gasudsivning $i \mathrm{dy}$ bet.

Det er muligt at estimere størrelsen af gasudsivningen fra en lækage i et forsejlet reservoir ved hjælp af en modificeret Darcy's lov. En kapillærlækage i en mudderstensforsejling i $3 \mathrm{~km}$ 's dybde er beregnet til at give en gasudsivning i størrelsesordenen $0.0015 \mathrm{~m}^{3} / \mathrm{m}^{2} /$ år ved det omgivende tryk eller $0.23 \mathrm{~m}^{3} / \mathrm{m}^{2} / a ̊ r$ i forhold til normalt overfladetryk. En sprækkelækage vil give en gasudsivning af væsentlig større omfang alt efter, hvor lang tid sprækkerne vil kunne stå åbne. De beregnede størrelser for gasudsivning ved kapillærlækage er i god overenstemmelse med størrelsesordenen af målte gasudslip ved jordoverfladen.

\section{References}

Dando, P. R., O'Hara, S. C. M., Schuster, U., Tayler, L. J., Clayton, C. J., Baylis, S. A. \& Laier, T. In Press Gas seepage from a carbonate-cemented sandstone reef on the Kattegat coast of Denmark. Mar. Petrol. Geol. (in press).

Eaton, B. A. 1969: Fracture gradient prediction and its application in oilfield operations. Jour. Pet. Tech., 21, 1353-1360.

England, W. A., Mackenzie, A. S., Mann, D. M. \& Quigley, T.M. 1987: The movement and entrapment of petroleum fluids in the subsurface. J. geol Soc. London, 144, 327-347.

Honda, H. \& Magara, K. 1982: Estimation of irreducible water saturation and effective pore size of mudstones. J. Petrol. Geol., 4, 407-418.

Hovland, M. \& Curzi, P. V. 1989: Gas seepage and assumed mud diapirism in the Italian central Adriatic Sea. Mar. Petrol. Geol., 6, 161-169.

Hovland, M. \& Sommerville, J. H. 1985: Characteristics of two natural gas seepages in the North Sea. Mar. Petrol. Geol., 2, 319-326.

Hough, E. W., Rzasa, M. J. \& Wood, B. B. 1951: Interfacial tensions at reservoir pressures and temperatures; apparatus and the water-methane system. Petrol Trans., AIME, 192, 57-60.

Mann, D. M. \& Mackenzie, A. S. 1990: Prediction of pore fluid pressures in sedimentary basins. Mar. Petrol. Geol., 7, 55-65.

Parsons, R. W. 1966: Permeability of idealised fractured rock. Soc. Pet. Eng., 6, 126.

Schowalter, T. T. 1979: Mechanics of secondary hydrocarbon migration and entrapment. Am. Assoc. Petrol. Geol. Bull., 63, $723-60$.

Walsh, J. B. 1965: The effect of cracks on compressibility of rock. J. Geophys. Res., 91, 7517-7530.

Watts, N. L. 1987: Theoretical aspects of cap-rock and fault seals for single- and two-phase hydrocarbon columns. Mar. Petrol. Geol., 4, 274-307. 